\title{
Application of knowledge management tools: Comparative analysis of small, medium, and large enterprises
}

\author{
Natalia Sytnik ${ }^{1}$ (D), Maryna Kravchenko ${ }^{2}$
}

\begin{abstract}
PURPOSE: The purpose of this study was to conduct a comparative analysis of knowledge management (KM) initiatives in small, medium, and large enterprises operating in Ukraine, and to highlight the specific characteristics of KM policies, as well as the scope and intensity of KM tools application in these categories. In particular, the study focused on the consistency between the awareness of knowledge/KM importance and KM policies, and the scope and intensity of the application of both human-centered tools and information communication technology (ICT) tools. METHODOLOGY: The concept of the study was developed on the basis of an integrative socio-technical perspective. The empirical data were obtained through a questionnaire survey among 90 managers of small, medium, and large Ukrainian enterprises and were analyzed statistically. FINDINGS: Both common and distinctive characteristics of these categories in terms of KM were highlighted. Although all enterprises, regardless of their size, showed a high awareness of knowledge/KM importance for their business, significant distinctions between small and large enterprises were found with regard to their KM policies, the scope of advanced KM tools application, and the intensity of some traditional and advanced KM tools application. In all cases, large enterprises showed higher levels of these characteristics compared to small enterprises, whereas medium enterprises were more similar to large enterprises. In contrast to the common view on SMEs as a homogeneous sector in terms of KM, the study shows its heterogeneity in terms of $K M$ initiatives. According to a number of indicators studied, significant differences were observed between small and large enterprises, whereas the distinctions between medium and large enterprises were much less obvious. IMPLICATIONS FOR THEORY AND PRACTICE: The theoretical contribution of this study was the provision

1 Natalia Sytnik, Associate Professor, National Technical University of Ukraine, "Igor Sikorsky Kyiv Polytechnic Institute", Peremogy Street, 37, Kyiv, 030566, Ukraine, e-mail: Natalia_Sytnik@ukr.net (ORCID: https://orcid.org/0000-0002-7670-8860). 2 Maryna Kravchenko, Professor, National Technical University of Ukraine, "Igor Sikorsky Kyiv Polytechnic Institute", Peremogy Street, 37, Kyiv, 03056 Ukraine, e-mail: marina.kravchenko.kpi@gmail.com (ORCID: https://orcid.org/00000001-5405-0159).
\end{abstract}


of SMEs sector heterogeneity evidence based on a number of KM characteristics. This finding allows us to deepen our knowledge of conceptual differences in KM approaches, applied by different enterprise categories. From a practical perspective, an enterprise size should be taken into account while designing specific KM policies, programs and tools to meet enterprises' needs to a greater extent. The larger the enterprise is, the more structured, deliberate, and conscious the KM approach that should be applied is. ORIGINALITY AND VALUE: No empirical research that addresses the comparative analysis of KM initiatives in small, medium, and large enterprises operating in Ukraine, as well as in other transition economies of post-Soviet states, has been previously performed, and this study fills the gap.

Keywords: knowledge management, knowledge management awareness, knowledge management policy, human-centered tools, ICT tools, small, medium, and large enterprises

\section{INTRODUCTION}

Nowadays, knowledge management (KM) is generally recognized as a profound factor of economic development, innovations, competitiveness, long-term organizational survival, and sustainability (Xue, 2017; Zheng, 2017; Susanty, Yuningsih, \& Anggadwita, 2019; Cardoni, Zanin, Corazza, \& Paradisi, 2020). The vital necessity to manage organizational knowledge in a more effective manner has been giving an impetus for rapid development of KM concepts, models, and tools. According to the knowledge-based view (KBV) of the firm, knowledge is seen as the most strategically important intangible asset of organizations and a critical source of competitive advantage (Grant, 1996; Spender, 1996).

$\mathrm{KM}$ is regarded as the deliberate and systematic coordination of employees, technology, processes, and organizational structure in order to add value through knowledge reuse and innovation (Dalkir, 2017). KM provides integration of some organizational processes like planning, organizing, motivating, and controlling of employees, designed and used systematically to ensure effective employment of an organization's knowledge-related assets (King, 2009). Until recently, a mainstream of the studies in the KM domain has been focused on large enterprises in which KM advantages are more visible, as compared to the sector of small and medium enterprises. Removing barriers in organizational knowledge acquisition, transfer, dissemination, and usage gives large enterprises a wide range of advantages in terms of business efficiency, vocational learning, and customer interactions (e.g., Uriarte, 2008; Becerra-Fernandez \& Sabherwal, 2010). Although the SMEs sector plays a pivotal role in many world economies and represents $99 \%$ of all businesses in the EU (European Commission, 2016), only 16\% of the literature devoted to KM is focused on small enterprises (Prystupa-Rządca, 2014). Some authors 
(Serenko, 2013; Durst \& Brunes, 2018; Centobelli, Cercione, \& Esposito, 2019) argue that KM in SMEs still remains an underestimated area that has not received sufficient attention in previous KM studies. Based on an extensive literature review, Massaro, Handley, Bagnoli, and Dumay (2016, p. 281) concluded that "literature on KM in SMEs is fragmented, with few specialized authors, and is dominated by unrelated research mainly originating in other contexts (e.g., larger organizations)."

The following gaps in studying the SMEs sector, as compared to large enterprises, were found. Although specific features influencing KM adoption, benefits, and obstacles for KM implementation in SMEs are well documented (Desouza \& Awazu, 2006; Hutchinson \& Quintas, 2008; Edvardsson \& Durst, 2013), the research contributions concerning KM tools and practices adopted by SMEs are fragmented and less systematic. Extensive research in this area with a focus on high-tech startups has only recently been launched (Evangelista, Esposito, Lauro, \& Raffa, 2010; Cerchione \& Esposito, 2017).

Another gap in the literature coverage deals with KM comparisons among small, medium, and large enterprises. Firstly, the quantitative comparisons between SMEs and large enterprises are quite scarce in spite of a general consensus among scholars that SMEs, in contrast to large enterprises, manage their organizational knowledge in different ways. Secondly, in a KM context, small and medium enterprises are implicitly treated as a single group, although the arguments for this view are insufficient. As Massaro, Handley, Bagnoli, and Dumay (2016, p. 281) stated, "different kinds of organizations (e.g., micro, small and medium) are sometimes treated as equivalent, making comparisons between studies hard."

In addition, the empirical research on KM initiatives in Ukrainian enterprises is very scarce. Existing literature contributions in this area are mainly concerned with the theoretical issues of KM. (Polyakov, 2017; Ситник, 2017; Ілляшенко, Шипуліна, \& Ілляшенко, 2019). To the best of our knowledge, no empirical research addressing the issues of $K M$ in various enterprise categories has been performed in the transition economies of post-Soviet states.

The present study was initiated to conduct a comparative analysis of KM initiatives in small, medium, and large enterprises operating in Ukraine and highlight the specific characteristics of KM policies (procedures), as well as the scope and intensity of KM tools application in these categories.

The research was carried out in a sample of Ukrainian enterprises located in Kyiv city and its region. The paper is organized to contain a number of sections. Following this introduction, the literature review section outlines the main findings in the KM domain regarding organizational knowledge and $\mathrm{KM}$ processes, initiatives, and factors influencing their implementation and 
effectiveness. The outcome of the literature review allows three research questions of this paper to be determined. The methodology section describes the main features of the sample investigated, the questionnaire survey, and the methods of statistical data analysis that have been applied. The results emerging from the questionnaire survey analysis are presented in the research results section. Both common and distinctive characteristics of KM attitudes, policies and KM tools application in various enterprise categories are highlighted. In the discussion section, the major findings of the study are discussed and compared with literature contributions. The conclusion section outlines the major findings of the study, the theoretical contribution, practical implications, limitations of the study, and suggestions for future research.

\section{LITERATURE REVIEW}

\section{Organizational knowledge and knowledge management}

During the last decades, the global economy has been facing a transformation from the era based on natural resources to the era of knowledge, in which knowledge has become a strategic asset and a dominant enabler of organizational development, performance, and competitiveness (Xue, 2017; Zheng, 2017; Susanty et al., 2019; Cardoni et al., 2020). Current definitions of knowledge reflect a wide diversity of its understanding among researchers. Some scholars consider knowledge as a source of valued organizational information and place emphasis on its informational side. Bergeron (2003) claims that knowledge incorporates information that is organized, synthesized, or summarized to enhance comprehension, awareness or understanding. According to Anand and Walsh (2016), knowledge consists of information, skills, and expertise.

Another pool of knowledge definitions is based on greater recognition of its social nature. Being socially constructed, knowledge is originated in people's minds and shaped by their values, experiences, and insights. The knowledge is recognized as "a fluid mix of framed experience, values, contextual information, and expert insight that provides a framework for evaluating and incorporating new experiences and information" (Davenport \& Prusak, 1998, p. 5).

Within the frame of the firm's KBV, knowledge is recognized as the most important intangible asset of organizations and a source of sustainable competitive advantage (Grant, 1996; Spender; Zheng, 2017). The firm is viewed as the institution that integrates its members' specialist knowledge with knowledge characteristics and its production requirements 
(Grant, 1996). The KBV emphasizes the social nature of organization and the role of internal organizational factors in knowledge production. To manage knowledge, the firm should manage its internal characteristics, which create a proper context for knowledge enhancing and utilization. The most valuable asset of the organization is its shared tacit knowledge (collective knowledge). Since collective knowledge exists throughout the employees' interaction process, rather than in their minds or databases, social factors such as communication and collaboration play a vital role in the utilization and coordination of knowledge resources (Spender, 1996).

The growing necessity to leverage knowledge assets and get the most benefit from their exploitation, forces companies to manage their knowledge through the development of specific KM policies, programs, procedures, and tools. It puts KM on the agenda of both academic researchers and practitioners.

The mainstream KM definitions have originated within the businessoriented KM approach. Knowledge management is recognized as "the capacity (or processes) within an organization to maintain or improve organizational performance based on experience and knowledge" (Pan \& Scarbrough, 1999, p. 360). KM is seen as managing the context and conditions, under which knowledge can be created, communicated, and used to achieve organizational goals (Von Krogh, Ichijo, \& Nonaka, 2000). In terms of organizational practices, $\mathrm{KM}$ means the integration of some organizational processes like planning, organizing, motivating, and controlling of employees, designed and used systematically to ensure the effective employment of an organization's knowledge-related assets (King, 2009).

Organizations apply KM in order to foster knowledge life cycle processes involving knowledge capturing, creation, sharing, storage, and exploitation (King, 2009; Dalkir, 2017). From a knowledge life cycle perspective, KM could be considered as a process that enhances organizational abilities in finding, selecting, organizing, disseminating, and transferring knowledge to support necessary activities such as problem solving, learning, strategic planning, and decision making within the organization (Gupta, lyer, \& Aronson, 2000). KM is also recognized as a set of activities that provide the generation, growth, application, and sustainability of intellectual capital in organizations (Marr, Gupta, Pike, \& Roos, 2003; Paolini, Coluccia, Fontana, \& Solimene, 2020). Drawing upon knowledge tacit-explicit dichotomy, Hansen, Nohria, and Tierney (1999) proposed a taxonomy of KM strategies that distinguishes between a people-centered "personalization" strategy and an ICT-focused "codification" strategy. 


\section{Knowledge management in SMEs and large organizations}

It is well known that large organizations, as well as SMEs, can benefit from KM implementation. Large organizations can leverage KM initiatives to improve their performance, efficiency and productivity, product quality, business processes, customer satisfaction, employees' behavior, as well as to enhance market standing, promotion of innovations, and intellectual capital (e.g., Du Plessis, 2005; Greiner, Bohmann, \& Krcmar, 2007; Gourova, 2010; Dalkir, 2017). The reported benefits of KM in the SMEs sector include sales and productivity growth, organizational processes improvement, better decision making and knowledge sharing, higher employee creativity and innovation, higher customer satisfaction, less work duplication, enhanced market relations, etc. (Wong \& Aspinwall, 2004; Singh, Garg, \& Deshmukh, 2008; Soon \& Zainol, 2011, Durst \& Brunes, 2018).

The managers of large enterprises demonstrate a high awareness of KM importance (e.g., Becerra-Fernandez \& Sabherwal, 2008; Uriarte, 2008; Dalkir, 2017). They make deliberate efforts to design KM policies and initiate KM programs in order to achieve their organizational goals. Despite the evident benefits of KM initiatives, SMEs differ from large enterprises in terms of their attitude to KM adoption. KM development does not often belong to the priorities of SME managers. They show insufficient awareness of the organizational needs in KM initiatives and an unwillingness to invest both financial and human resources into developing KM programs (Wong \& Aspinwall, 2004; Gourova, 2010).

SMEs differ from large enterprises by their constrained resources and comparatively poor managerial capabilities and practices (Pinget, Bocquet, \& Mothe, 2015). They tend to focus on day-to-day operational activities and rely on short-term planning to the detriment of strategical thinking. As a result, small enterprises rarely develop an explicit KM policy (Hutchinson \& Quintas, 2008), and often adopt a short-term, unstructured approach towards organizational learning (Edvardsson \& Durst, 2013). SMEs are more likely to use informal procedures to manage knowledge than apply deliberate KM programs (Hutchinson \& Quintas, 2008). Many scholars underline that smaller enterprises do not fully exploit KM potential and, compared to large organizations, they are much slower in introducing KM initiatives (Gourova, 2010; Evangelista et al., 2010; Durst \& Edvardsson, 2012).

Since SMEs are resource constrained, they look outside the organization to capture the relevant knowledge. They are considered to be less advanced in knowledge creation (McAdam \& Reid, 2001; Desouza \& Awazu, 2006). Due to multiple responsibilities, SME employees often have little time to devote to knowledge codification. SME's organizational knowledge is stored 
predominantly in managers' and employees' minds in tacit form (Desouza \& Awazu, 2006). Due to the lack of explicit knowledge repositories, SMEs can suffer from organizational "amnesia" as they often fail to retain knowledge acquired and lessons learned in the past, and are more influenced by employee turnover (Gourova, 2010).

At the same time, some specific features of SMEs potentially make them capable of stimulating and supporting knowledge-sharing processes (Alexandru et al., 2019). Due to their structure and size, SMEs are more flexible than large firms, and these traits increase their reactivity (Pinget et al., 2015). Desouza and Awazu (2006) underline that SMEs are very social entities who rely highly on close personal relations among their employees, and have a knack for exploiting external sources of knowledge. Such SMEs' features, such as flat structures and fewer management levels, less bureaucracy, close everyday communications among employees, and rather simple business procedures, serve as prerequisites to their socialization (McAdam \& Reid, 2001; Singh et al., 2008). This process of socialization allows small enterprises to form the deep common knowledge they need for organizing their work by easing knowledge transfer and application (Desouza \& Awazu, 2006).

$\mathrm{KM}$ practices (tools) are conceptualized as the set of various management activities enabling the company to deliver value from its knowledge-based assets supporting the organizational processes of knowledge creation, storage, and transfer (Inkinen, Kianto, \& Vanhala, 2015). Human-centered tools incorporate methods and techniques based on "person-to-person" communications and facilitate tacit knowledge sharing. ICT tools are the set of specific IT-based techniques supporting mainly explicit knowledge sharing.

A quantitative investigation of KM tools used by high-tech SMEs was conducted by Cerchione and Esposito (2017). Studying high-tech SMEs, the authors came to the conclusion that SMEs adopted and made more intensive use of those human-centered tools (practices) that did not exclusively focus on the knowledge management process (problem solving, learning by doing, team meetings, and work groups). KM specific, human-centered tools like knowledge elicitation interviews, knowledge modeling, knowledge office, knowledge cafes, communities of practice, and knowledge filtering were less exploited. High-tech SMEs adopted and used more intensively traditional ICT tools rather than new and more updated ones even if they were cheaper and easier to use. More advanced ICT tools (podcasting, video casting, data mining, social media, mash-up, syndication systems, collaborative filtering, crowdsourcing) were less common (Cerchione \& Esposito, 2017). In contrast to large organizations, SMEs apply a more careful and leaner approach in terms of ICT tools supporting KM (Singh et al., 2008). Lately, Centobelli et al. 
(2019) proposed a methodology to assess the efficiency and effectiveness of knowledge management systems adopted by SMEs.

In recent years, the strategic aspects of KM in SMEs have been the focus of a number of studies (Cerchione \& Esposito, 2017; Zieba, Bolisani, \& Scarso, 2016; Bolisani, Zieba, Paiola, \& Scarso, 2017).

Studying SMEs in the IT sector, Zieba et al. (2016) suggested two opposite approaches to KM. The authors defined them as a deliberate (planned) and emergent approach. The essential features of these approaches were identified as follows. While applying a deliberate KM approach, organizations link their KM practices, tools and methods to the general strategic orientation: their KM procedures are deliberately designed by top management, their KM goals are based on a rational analysis of the organization's needs, objectives and resources; their KM practices are implemented and spread across the company with deliberate efforts and investments.

The emergent KM approach includes KM practices, tools, and methods that originate from the organization's employees' daily activities and learning processes. In fact, employees develop their own methods of knowledge processing in relation to their actual needs. The methods that prove to be effective, useful and/or compatible with the daily business activity are developed and become established practices, and can be recognized as "the KM approach" of the organization (Bolisani et al., 2017). Further development of ideas about the deliberate versus emergent approach was made in the Alexandru et al. (2019) study based on the data from knowledge-intensive SMEs. Three clusters of SMEs were distinguished, that differ in their attitude to KM and the use of KM practices, which the authors called "conscious adopters," "unconscious adopters," and "marginal adopters."

In contrast to SMEs, large organizations are less dependent on external sources of knowledge and make strong efforts to create their own knowledge. In large enterprises, common knowledge can be blurred or fragmented due to the interdepartmental barriers in communications. Therefore, large enterprises have to make greater efforts in order to save and distribute their organizational knowledge. One of the ways to do so leads them to the adoption of a codification strategy based on intensive use of ICT tools (Maier, 2002; Sun \& Scott, 2005; Subashini, Rita, \& Vivek, 2012; Merlo, 2016). Large enterprises invest generously in the implementation of sophisticated ICT tools to store explicit organizational knowledge. The ICT is proven to be a vital factor to enhance and advance their KM programs (Alavi \& Leidner, 2001; Sun \& Scott, 2005; Subashini et al., 2012; García-Álvarez, 2015; Dalkir, 2017). ICT tools assist in facilitating knowledge acquisition/creation, knowledge dissemination, knowledge conversion, and knowledge utilization (Cantú, Criado, \& Criado, 2009; Martelo-Landroguez \& Cegarra-Navarro, 2014). 
To sum up, it is generally accepted that large enterprises and SMEs manage their knowledge in different ways. However, this point of view is based on logic and theoretical reasoning rather than on comparable empirical data. Our review of the literature confirms the validity of the conclusions made by Serenko (2013) and Massaro et al. (2016) on the lack of empirical data that allow quantitative comparisons among small, medium, and large enterprises.

In terms of small, medium, and large enterprise distinctions, the latest literature contributions on KM policies and KM tools application should be summarized as follows:

- a majority of the studies in the KM domain has been devoted either to large enterprises or SMEs with a strong prevalence of the studies focused on large enterprises;

- implicitly, small and medium-sized enterprises have been considered as a homogeneous group with similar KM requirements, policies, and initiatives;

- the empirical data on SMEs and large enterprises were predominantly collected on the basis of different methodological approaches and research tools;

- the latest research on KM tools application in SMEs has been conducted in knowledge-intensive SME sectors, whereas traditional business sectors (e.g., manufacturing and trade services) receive less attention from researchers;

- there is no empirical data on KM initiatives in Ukraine. Due to political, economic and cultural differences, application of KM practices and tools among Ukrainian enterprises might differ from the transitional economies of Eastern and Central Europe.

The foregoing statements are evidence that drawing comparisons between small, medium and large enterprises can be difficult and unjustified. Bearing in mind these findings, the following research questions (RQ) were formulated:

RQ1: Do small, medium, and large Ukrainian enterprises differ in their awareness of knowledge/KM importance?

RQ2: Do small, medium, and large Ukrainian enterprises apply distinctive KM policies?

RQ3: Do small, medium, and large Ukrainian enterprises differ in the scope of $K M$ tools application?

RQ4: Do small, medium, and large Ukrainian enterprises differ in the intensity of KM tools application? 


\section{METHODOLOGY}

A holistic and deep understanding of complex social phenomena like KM requires the application of a multi-paradigmatic approach to the research. The concept of the study was developed on the basis of an integrative, sociotechnical perspective on KM proposed by Jelavic (2011). Taking into account a mutual explicit-tacit dependency of KM processes, a holistic approach adopted by a socio-technical perspective assumes that KM research requires exploring both human and technical factors within an organizational context (Pan \& Scarbrough, 1999; Jelavic, 2011). Within the frame of this perspective, both human-centered and ICT tools were investigated as the key elements of a socio-technical system supporting KM processes in organizations. The organizational context of $\mathrm{KM}$ tools application was assessed through the analysis of KM attitudes and the level of formalization of KM policies.

The interpretive perspective was applied at the stage of questionnaire development, its pilot testing, and distribution. The qualitative analysis of feedback from the experts was conducted to validate the questionnaire. On the basis of intensive focus group discussions, the initial questionnaire content was reconsidered. The final version of the questionnaire was obtained through the pilot testing of the questionnaire and its discussion among the managers of four enterprises from the sample surveyed. The functionalist perspective in $\mathrm{KM}$ is based on the idea that knowledge is an explicit object that manifests itself in a multitude of forms and locations, including individuals and organizations, and can be detached, codified, and transmitted (Jelavic, 2011). The functionalist perspective was used at the stage of data collection and statistical analysis.

The survey was carried out in a sample of small, medium, and large Ukrainian enterprises. Given the exploratory nature of this study, a convenience sample was used. Convenience sampling is a commonly applied method in social science, and it is particularly recommended in the case of exploratory studies (Leiner, 2017). The study sample was formed from enterprises which during 2015-2019, were partners of Igor Sikorsky Kyiv Polytechnic Institute on the vocational training programs for Management and Marketing Department students. The overall list of partners includes 253 enterprises of various industries located in Kyiv city and Kyiv region. Among them, almost $80 \%$ of enterprises are medium and large. The actual data collection was conducted in two stages: 1) on the basis of the partners' list for 2015-2018 - in November-December 2018, and 2) on the basis of the partners' list for 2019 - in December 2019. All potential participants received an e-mail invitation to participate in the study. The number of enterprises that agreed to participate and, thus, included in the sample, was 90 . Hence, 
the response rate was $35.6 \%$. Further contact with the participants took place at a time convenient for them in the form of a face-to-face interview. Since the respondents belonged to enterprises with which the faculty cooperated throughout different years, in fact, a "convenience pool" was used. Respondents formed two convenience samples, which allowed us to reduce one of the most substantial biases of this method - the sample's homogeneity (Leiner, 2017).

The respondents were aged from 25 to 45 years, had a university degree in management and occupied managerial positions. Their total length of service varied from 3 to 15 years and 60\% of them had been working with the respective sample enterprise for over 3 years. The enterprise category was defined according to staff headcount as proposed by the EU Commission (European Commission, 2016). The breakdown of respondents according to the enterprise category is shown in Table 1.

Table 1. Breakdown of enterprises according to the enterprise category

\begin{tabular}{lll}
\hline Category & Number of enterprises & $\%$ \\
\hline Small (between10 and 49 employees) & 29 & 32.2 \\
Medium (50-250) & 30 & 33.3 \\
Large (over 250 employees) & 31 & 34.5 \\
\hline Total & 90 & 100.0 \\
\hline
\end{tabular}

The breakdown of enterprises according to their business sector is shown in Table. 2.

Table 2. Breakdown of enterprises according to business sector

\begin{tabular}{lll}
\hline Business Sector & Number of enterprises & $\%$ \\
\hline Trade & 29 & 32.3 \\
Financial and legal services & 17 & 18.9 \\
IT & 15 & 16.8 \\
Manufacturing & 9 & 10.0 \\
Construction & 4 & 4.4 \\
Transport & 4 & 4.4 \\
Household services & 4 & 4.4 \\
Entertainments & 4 & 4.4 \\
Educational services & 2 & 2.2 \\
Restaurants & 2 & 2.2 \\
\hline Total & 90 & 100.0 \\
\hline
\end{tabular}


According to Table 2, trade enterprises make up almost a third of the enterprises surveyed. Financial, legal, and IT enterprises constituted roughly another third of the sample. The last third combined enterprises from seven business sectors, including manufacturing, construction, transport, household services, entertainment, educational services, and restaurants.

There were some limitations with the sampling. One clear limitation of the study is the relatively small number of respondents involved. Further, the sample was not fully representative regarding the structure of small, medium, and large enterprises in the country, and it was not random. Such sampling was made intentionally with a twofold purpose. Firstly, it allowed us to increase the representation of large enterprises in the sample, which was important in terms of the statistical analysis of the results. Secondly, it allowed us to distribute the questionnaire among owners, executives, and senior managers during face-to-face interviews. Personal communications allowed us to provide an insight into the current situation with regard to KM adoption within domestic enterprises. In the case of an online survey, senior managers would have been hardly available and the results of the study would have been compromised. Another limitation of this study is related to the geographical location of the enterprises studied. All of them were located in Kyiv city and Kyiv region. In order to investigate the above stated research questions, a method of standardized questionnaire survey was applied.

The questionnaire was designed to obtain the background characteristics of the sample enterprises and receive answers to the research questions 1-4. In order to construct the initial list of survey questions, an extensive literature review concerning quantitative measures of $\mathrm{KM}$ awareness and policies, human-centered tools, and ICT tools was performed (KPMG Consulting, 2000; Alavi \& Leidner, 2001; Uriarte, 2001; Becerra-Fernandez \& Sabherwal, 2010; Massaro et al., 2016; Cercione \& Esposito, 2017).

In order to validate the questionnaire, the initial list of questions was presented to focus group for comments and discussion. The focus group involved six senior managers from small, medium, and large enterprises. They evaluated the questions in terms of their relevance to enterprise practices, ease of understanding, and clarity. As a result of the feedback received, the list of initial questions was revised. The total number of questions was decreased and some of them were reformulated to avoid ambiguity. The experts' revision allowed us to reduce the original list of human-centered tools from twenty to fifteen items and the list of ICT tools was shortened from twenty-four to fifteen items. Such ICT tools as syndication systems, podcasting, video casting, mash-up, prediction and idea markets, trust and reputation systems, product life cycle management systems, collaborative filtering and configuration management systems were excluded from the 
final version of the survey as rather "exotic" for Ukrainian realities. For the final revision, the pilot testing of the questionnaire was carried out in four enterprises from the sample surveyed.

The overall structure of the questionnaire is presented in Table 3. The questions were grouped into four sections. The background information section was concerned with the general characteristics of an enterprise, section 1 included the questions on awareness of knowledge and KM importance, section 2 included the questions on KM policies. Sections 1 and 2 combined 3- or 2-choice questions, as well as Likert-scale type questions.

Table 3. Structure of questionnaire sections

\begin{tabular}{|c|c|c|}
\hline $\begin{array}{l}\text { Questionnaire } \\
\text { Section }\end{array}$ & Variables & $\begin{array}{l}\text { Number of } \\
\text { Questions }\end{array}$ \\
\hline $\begin{array}{l}\text { Background } \\
\text { information on } \\
\text { enterprises and } \\
\text { respondents } \\
\text { surveyed }\end{array}$ & $\begin{array}{l}\text { Enterprise business sector } \\
\text { Total number of employees } \\
\text { Respondent age } \\
\text { Respondent education } \\
\text { Respondent occupied position } \\
\text { Respondent length of service }\end{array}$ & 6 \\
\hline 1. KM awareness & $\begin{array}{l}\text { Awareness of knowledge importance as a factor of } \\
\text { enterprise competitiveness } \\
\text { Awareness of KM importance as a factor of enterprise } \\
\text { business success }\end{array}$ & 2 \\
\hline $\begin{array}{l}\text { 2. KM policies } \\
\text { (programs) }\end{array}$ & $\begin{array}{l}\text { Availability of a formal KM policy } \\
\text { Availability of a formal staff training program in an } \\
\text { enterprise } \\
\text { Availability of activities that are specified as KM } \\
\text { activities } \\
\text { Availability of a person(s) responsible for KM activities } \\
\text { in the company }\end{array}$ & 4 \\
\hline $\begin{array}{l}\text { 3. Human-centered } \\
\text { tools exploited by } \\
\text { an enterprise }\end{array}$ & $\begin{array}{l}\text { Staff meetings } \\
\text { Conferences/exhibitions } \\
\text { Brainstorming } \\
\text { Off-site vocational training } \\
\text { Mentoring/coaching } \\
\text { Learning by doing } \\
\text { Working groups } \\
\text { Communities of practice } \\
\text { Job rotation } \\
\text { Collaborative problem-solving sessions (CPSS) } \\
\text { Previous experience analysis } \\
\text { Best practices analysis } \\
\text { Knowledge maps } \\
\text { Process maps } \\
\text { Benchmarking }\end{array}$ & 15 \\
\hline
\end{tabular}




\begin{tabular}{|c|c|c|}
\hline $\begin{array}{l}\text { Questionnaire } \\
\text { Section }\end{array}$ & Variables & $\begin{array}{l}\text { Number of } \\
\text { Questions }\end{array}$ \\
\hline $\begin{array}{l}\text { 4. ICT- tools } \\
\text { exploited by an } \\
\text { enterprise }\end{array}$ & $\begin{array}{l}\text { E-mail } \\
\text { Social technologies (discussion forums, blogs, etc.) } \\
\text { Skype sessions } \\
\text { Audio/video conferences } \\
\text { E-learning } \\
\text { Data bases } \\
\text { Document management systems (DMS) } \\
\text { Customer relationship management systems (CRM } \\
\text { systems) } \\
\text { ERP systems } \\
\text { Files/documents archives } \\
\text { Groupware tools } \\
\text { Decision-making systems } \\
\text { Expert systems } \\
\text { Cloud computing } \\
\text { Data mining }\end{array}$ & 15 \\
\hline
\end{tabular}

Sections 3 and 4 combined the questions concerning the application of human-centered tools and ICT tools application accordingly. They consisted of Likert-scale type questions with a 5-point scale incorporating options varying from "Never" to "Constantly." The questions were used to measure the scope and intensity of specific KM tool application in the company. For each enterprise category, the scope of specific KM tool application was calculated as the percentage of enterprises which exploited this KM tool "Rarely," "Sometimes," "Often," and "Permanently." The scope of specific KM tool application could range from 0 , if no enterprise exploited the tool, to 100 , if all enterprises exploited it.

Our questionnaire survey incorporated self-reported data from a single source. In view of this, potential risk of the common method bias (CMB) was considered. In fact, the questions from sections 2-4 provided data that could be independently verified from other sources. Such questions cause a lower risk of CMB than purely attitudinal questions (Podsakoff \& Organ, 1986). Nevertheless, to minimize CMB risk, a number of remedies were applied, as suggested by Podsakoff, MacKenzie, Lee, and Podsakoff (2003). In particular, the questions were kept as simple, focused, and concise as possible, double-barreled questions were avoided, and respondent anonymity along with the exclusive research purpose of the study was reiterated. To check for $\mathrm{CMB}$, correlations between variables were calculated. According to Podsakoff et al. (2003), high variable correlations indicate a high level of CMB. The highest correlation coefficient $(0.605)$ did not exceed 0.90 which was suggested by Bagozzi, Yi, and Phillips (1991) as 
the threshold for $\mathrm{CMB}$ assessment. So, the post-hoc test shows that $\mathrm{CMB}$ did not substantially confound the results obtained.

Since respondents' answers were measured on an ordinal scale, Pearson's Chi-square test was used to assess the statistical significance of differences in KM attitudes, KM policies (procedures) and the scope of KM tools application between enterprises surveyed. In all cases, the null hypothesis $\left(H_{0}\right)$ stated that the differences between obtained frequencies of observable variables in small, medium, and large enterprises were statistically insignificant ( $p>0.05)$. The alternative hypothesis $\left(H_{\mathrm{a}}\right)$ stated that the differences between obtained frequencies of observable variables in enterprises surveyed were statistically significant $(p \leq 0.05)$.

In order to measure the intensity of KM tools application, respondents' answers were recoded as follows: Never $=0$, Rarely $=1$, Sometimes $=2$, Often $=3$, Permanently $=4$. Hence the intensity of each specific tool application could range from 0 , if an enterprise had never exploited the tool, to 4 , if an enterprise had exploited it permanently.

One-Way ANOVA was performed with the enterprise category as an independent variable to investigate how enterprise category affects the intensity of human-centered and ICT-centered tools application. One-Way ANOVA was chosen since it is not particularly sensitive to data deviations from normal distribution. In all cases, the null hypothesis $\left(H_{0}\right)$ stated that the differences between observable intensities of a specific KM tool application in small, medium, and large enterprises were statistically insignificant ( $p>0.05)$. The alternative hypothesis $\left(H_{\mathrm{a}}\right)$ stated that the differences between observable intensities of a specific KM tool application in small, medium, and large enterprises were statistically significant $(p \leq 0.05)$.

For significant results $(p \leq 0.05)$, the Tukey-Kramer test was applied as a post-hoc test to One-Way ANOVA (Levine, Stephan, Krehbiel, \& Berenson, 2008). The procedure of Tukey-Kramer test allows one to define which pairwise comparisons between enterprises' categories were significant. Importantly, the test is applicable in case of abnormal data and unequal sample sizes. According to the Tukey-Kramer test, the values $X_{\mathrm{j}}-X_{\mathrm{j}^{\prime}}$ were calculated as differences between the means of $c(c-1) / 2$ groups $\left(i \neq i^{\prime}, c=\right.$ 3). Obtained values were compared with Tukey-Kramer's critical range (CR):

$$
C R=Q_{u} \sqrt{\frac{M S W}{2}\left(\frac{1}{n_{i}}+\frac{1}{n_{i^{\prime}}}\right)}
$$

where $Q_{u}$ - the upper critical value of the studentized range distribution, which has $c$ degrees of freedom in the numerator and $n-c$ degrees of 
freedom in the denominator ( $n$ - number of observations in the appropriate enterprise category), MSW - mean square within groups.

Since the quantity of enterprises in various categories was unequal, the critical range was calculated for each pair of means separately. Finally, each of the $c(c-1) / 2$ pairs of means were compared with the corresponding critical range. The elements of a pair were considered significantly different if the expression $\left|X_{\mathrm{i}}-X_{\mathrm{i}^{\prime}}\right|$ exceeded the critical range.

\section{RESEARCH RESULTS}

The study results are reported below in accordance with the research questions.

RQ1: Do small, medium, and large Ukrainian enterprises differ in their awareness of knowledge/KM importance?

The results concerning enterprise attitudes are presented in Table 4 . Questions 1.1 and 1.2 reflect the awareness of knowledge importance and awareness of KM importance, respectively. As Table 4 shows, the distributions of respondents' opinions from small, medium, and large enterprises were rather similar. For all categories studied, over $80 \%$ of respondents either strongly agree or somewhat agree that organizational knowledge is a factor of enterprise competitiveness. Nevertheless, large enterprises showed significantly higher scores on this question in comparison with medium and especially small enterprises. As far as Question 1.2 concerns, regardless of enterprise size, over $80 \%$ of respondents either strongly agree or somewhat agree that KM is a factor of business success for their enterprises. According to the Chi-square test, this finding was statistically significant.

Table 4. Awareness of knowledge and KM importance in small, medium, and large enterprises (\% of respondents' answers)

\begin{tabular}{|c|c|c|c|c|c|c|}
\hline \multirow[t]{2}{*}{ Category } & \multicolumn{5}{|c|}{$\begin{array}{l}\text { Question1.1. Managers consider knowledge as a } \\
\text { factor of enterprise competitiveness }\end{array}$} & \multirow[t]{2}{*}{$\begin{array}{l}\text { Level of } \\
\text { significance, } p\end{array}$} \\
\hline & $\begin{array}{l}\text { Strongly } \\
\text { disagree }\end{array}$ & $\begin{array}{l}\text { Somewhat } \\
\text { disagree }\end{array}$ & Neutral & $\begin{array}{l}\text { Somewhat } \\
\text { agree }\end{array}$ & $\begin{array}{l}\text { Strongly } \\
\text { agree }\end{array}$ & \\
\hline Small & 0.0 & 3.4 & 13.8 & 31.0 & 51.8 & 0.00975 \\
\hline Medium & 0.00 & 13.3 & 0 & 26.6 & 60.1 & \\
\hline Large & 0.0 & 6.5 & 0 & 16.1 & 77.4 & \\
\hline Total & 0.0 & 7.7 & 4.5 & 24.5 & 63.3 & 5.551E-17 \\
\hline
\end{tabular}




\begin{tabular}{|c|c|c|c|c|c|c|}
\hline & \multicolumn{5}{|c|}{$\begin{array}{l}\text { Question 1.2. Managers consider KM as a factor of enterprise } \\
\text { business success }\end{array}$} & \multirow{5}{*}{0.1214} \\
\hline & $\begin{array}{l}\text { Strongly } \\
\text { disagree }\end{array}$ & $\begin{array}{l}\text { Somewhat } \\
\text { disagree }\end{array}$ & Neutral & $\begin{array}{l}\text { Somewhat } \\
\text { agree }\end{array}$ & $\begin{array}{l}\text { Strongly } \\
\text { agree }\end{array}$ & \\
\hline Small & 0.0 & 6.9 & 10.3 & 31.1 & 51.7 & \\
\hline Medium & 0.0 & 0 & 16.6 & 23.4 & 60.0 & \\
\hline Large & 0.0 & 0 & 6.5 & 12.9 & 80.6 & \\
\hline Total & 0.0 & 2.3 & 11.1 & 22.2 & 64.4 & $1.1941 \mathrm{E}-17$ \\
\hline
\end{tabular}

RQ2: Do small, medium, and large Ukrainian enterprises apply distinctive KM policies?

The results concerning some general characteristics of $\mathrm{KM}$ policies applied by various categories of enterprises are presented in Table 5. Participants' responses to question 2.1 indicate that only a few small enterprises had an explicit KM policy in the form of an official document. Almost $40 \%$ of them did not have any KM policy at all and more than a half of them had informal KM policies. Although informal KM policies prevailed in all categories of enterprises, more than a third of medium and large enterprises had explicit $\mathrm{KM}$ policies in the form of an official document. Only 3\% of large enterprises had no KM policy. According to the Chi-square test, the differences between small, medium, and large enterprises concerning availability of KM policies were statistically significant.

As the respondents' reflections to question 2.2 indicate, all enterprises studied have staff training programs. However, $75 \%$ of small enterprises have informal training programs, in contrast to more than $50 \%$ of medium enterprises and more than $80 \%$ of large enterprises having explicit training programs in the form of an official internal document.

Statistically significant differences between the categories studied were also observed with regard to question 2.3. The question showed the level of identification of some enterprises' activities as KM activities. Respondents stated that only about $40 \%$ of small enterprises performed some organizational activities that were explicitly defined as KM activities, whereas such identification exceeded $66 \%$ in medium enterprises and $90 \%$ in large enterprises.

As for question 2.4, half of small enterprises have no person assigned to KM activities. At the same time, more than $80 \%$ of medium enterprises and $90 \%$ of large enterprises have a person(s) responsible for $\mathrm{KM}$. The differences between categories studied were statistically significant. 

and large enterprises

Table 5. KM policies (procedures) in small, medium, and large enterprises (\% of respondents' answers)

\begin{tabular}{lllll}
\hline Category & Question 2.1. Availability of KM policies & $\begin{array}{l}\text { Level of } \\
\text { significance, } \\
\end{array}$ & \multicolumn{3}{c}{\begin{tabular}{l} 
Non-available \\
\cline { 2 - 4 }
\end{tabular}} & Informal & $\begin{array}{l}\text { Formal, in a form of } \\
\text { official document }\end{array}$ & \\
Small & 37.9 & 55.1 & 7.0 & 0.00337 \\
Medium & 23.4 & 43.3 & 33.3 & \\
Large & 3.3 & 58.0 & 38.7 & \\
\hline
\end{tabular}

Question 2.2. Availability of staff training program

\begin{tabular}{lllll} 
& Non-Available & Informal & \multicolumn{2}{c}{$\begin{array}{l}\text { Formal, in a form of } \\
\text { official document }\end{array}$} \\
Small & 0.0 & 75.9 & 24.1 & 0.00001 \\
Medium & 0.0 & 46.6 & 53.4 & \\
Large & 0.0 & 19.4 & 80.6 & \\
\hline
\end{tabular}

Question 2.3. An enterprise conducts some activities explicitly identified as KM activities

\begin{tabular}{lllll} 
& No & Don't know & Yes & \\
Small & 24.1 & 34.5 & 41.4 & 0.00121 \\
Medium & 20.0 & 13.3 & 66.7 & \\
Large & 0.0 & 9.7 & 90.3 & \\
\hline
\end{tabular}

Question 2.4. Availability of a person(s) responsible for KM activities

\begin{tabular}{llll} 
& No & Yes & \multirow{2}{*}{0.00041} \\
Small & 48.2 & 51.7 & \\
Medium & 16.7 & 83.3 & \\
Large & 6.7 & 93.3 & \\
\hline
\end{tabular}

RQ3: Do small, medium, and large Ukrainian enterprises differ in the scope of $K M$ tools application?

The descriptive statistic on the scope of human-centered tools in the categories surveyed is shown in Table 6. In all categories, the scopes exceeded $60 \%$. The lowest average scope and the highest variation in the scope were observed in small enterprises, while the highest average scope with lowest variation was observed in large enterprises. 
Table 6. Scope of human-centered tools application: Means and coefficients of variations, (\%)

\begin{tabular}{lll}
\hline Category & Mean & Coefficient of Variation \\
\hline Small & 62.3 & 58.6 \\
Medium & 71.9 & 37.3 \\
Large & 77.3 & 29.9 \\
\hline
\end{tabular}

The scope of human-centered tools application among the categories studied is presented in Figure 1 . As Figure 1 depicts, staff meetings, CPSS, learning by doing, mentoring/coaching and brainstorming were the most commonly used human-centered tools in all categories. Their scope of application exceeded $90 \%$. Such tools as off-site vocational training, communities of practice, process maps and knowledge maps were the least exploited in all categories. According to the Chi-square test, statistically significant differences between the categories were observed on benchmarking, communities of practice, process maps and knowledge maps, indicating that these tools were less common in small enterprises as compared to medium and especially large enterprises.

For small enterprises, variations in the scope of human-centered tools application were the most visible. Tools like staff meetings and collaborative problem-solving sessions showed a $100 \%$ scope of application, while knowledge maps were applied only by $7 \%$ of small enterprises. In the case of medium and especially large enterprises, variations in the scope of humancentered tools application were less noticeable.

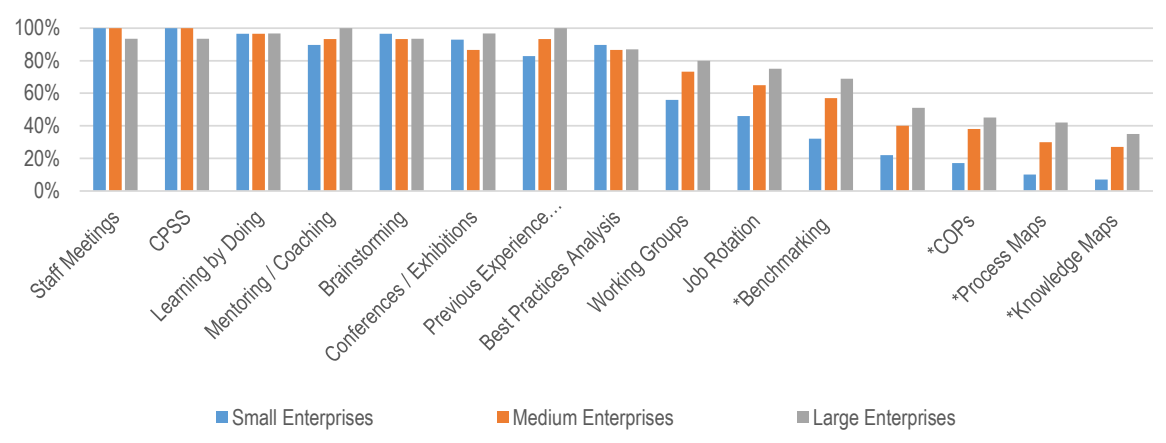

Figure 1. Scope of human-centered tools application in small, medium, and large enterprises

Note: ${ }^{*}$ - statistically significant differences between the categories, $p \leq 0,05$. 
Table 7 indicates that the mean values of ICT tools application were rather different in various categories of enterprises. The lowest mean was observed in small enterprises, whereas the highest mean was observed in large enterprises. On the contrary, the coefficient of variation was the highest for small enterprises and the lowest for large enterprises, indicating distinctive ranges of variations in categories means.

Table 7. Scope of ICT tools application: Means and coefficients of variations, (\%)

\begin{tabular}{lll}
\hline Category & Mean & Coefficient of variation \\
\hline Small & 43.5 & 92.1 \\
Medium & 55.5 & 56.3 \\
Large & 63.0 & 42.7 \\
\hline
\end{tabular}

Figure 2 shows that in all categories, the most exploited ICT tools were e-mail, data bases, social technologies and file archives. Their scope of application exceeded $90 \%$. On the contrary, DMS, document management systems, ERP systems, cloud computing, expert systems, data mining, and groupware tools showed a rather low scope of application in all groups.

Even so, some distinctions between various categories were observed. For the vast majority of ICT tools studied, their scope of application was higher in large enterprises as compared to medium and especially small enterprises. According to the Chi-square test, the significant differences among the categories were found with regard to decision-making systems, ERP-systems, cloud computing, expert systems, data mining, and groupware tools $(p \leq 0.05)$.

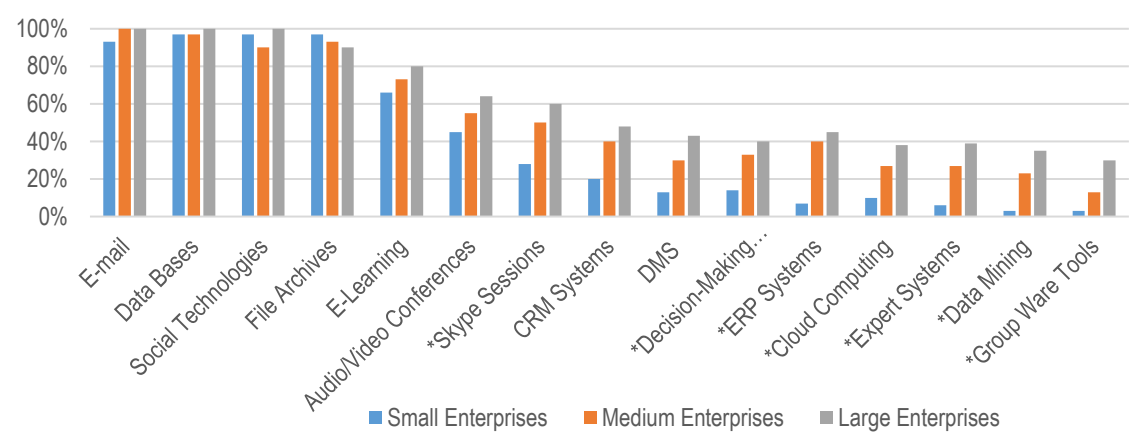

Figure 2. Scope of ICT tools application in small, medium, and large enterprises

* - statistically significant differences between the categories, $p \leq 0,05$. 
RQ4: Do small, medium, and large Ukrainian enterprises differ in the intensity of KM tools application?

The distinctions in intensity of KM tools application between various categories were assessed according to ANOVA. The means of seven out of fifteen human-centered tools differed significantly between the categories studied $(p \leq 0.05)$. Significant results are presented in Table 8 . They indicate that small, medium, and large enterprises exploited conferences/exhibitions, previous experience analysis, mentoring/coaching, working groups, job rotation, off-site vocational training, and knowledge maps with different intensity. To conduct pairwise comparisons between enterprise categories, a post-hoc Tukey-Kramer test was applied. Its results (Table 8) show that in the vast majority of cases, the means of large and small enterprises were significantly distinctive. Small-medium enterprises pairwise comparisons, as well as medium-large enterprises comparisons, did not demonstrate many significant distinctions. Significant differences were observed for working groups in the pair of small-medium enterprises and for conferences/ exhibitions in the pair of medium-large enterprises only.

Table 8. Intensity of human-centered tools application in small, medium, and large enterprises

\begin{tabular}{lllllll}
\hline Tools & $\begin{array}{l}\text { Small } \\
\text { (S) }\end{array}$ & $\begin{array}{l}\text { Medium } \\
\text { (M) }\end{array}$ & $\begin{array}{l}\text { Large } \\
\text { (L) }\end{array}$ & F-value & $\begin{array}{l}p \text {-value } \\
\text { (significance) }\end{array}$ & $\begin{array}{l}\text { Significant } \\
\text { differences } \\
\text { between groups } \\
\text { by Tukey-Kramer } \\
\text { test }\end{array}$ \\
\hline $\begin{array}{l}\text { Conferences/ } \\
\text { exhibitions }\end{array}$ & 2.44 & 1.93 & 3.00 & 6.56 & 0.0022 & M-L \\
$\begin{array}{l}\text { Previous } \\
\text { experience }\end{array}$ & 2.07 & 2.80 & 2.87 & 4.08 & 0.0203 & S-L \\
$\begin{array}{l}\text { analysis } \\
\begin{array}{l}\text { Mentoring / } \\
\text { coaching }\end{array}\end{array}$ & 2.37 & 2.80 & 3.32 & 5.59 & 0.0052 & S-L \\
$\begin{array}{l}\text { Working } \\
\text { groups }\end{array}$ & 0.93 & 1.93 & 2.48 & 10.33 & $9.41 \mathrm{E}-05$ & $\mathrm{~S}-\mathrm{M}, \mathrm{S}-\mathrm{L}$ \\
$\begin{array}{l}\text { Job rotation } \\
\text { Off-site }\end{array}$ & 0.82 & 1.57 & 2.03 & 6.92 & 0.0016 & $\mathrm{~S}-\mathrm{L}$ \\
$\begin{array}{l}\text { vocational } \\
\text { training } \\
\text { Knowledge } \\
\text { maps }\end{array}$ & 0.38 & 0.76 & 1.48 & 6.25 & 0.0029 & $\mathrm{~S}-\mathrm{L}$ \\
\hline
\end{tabular}


Further, One-Way ANOVA was conducted to analyze the intensity of ICT tools application. Significant One-Way ANOVA results were obtained for nine out of fifteen ICT tools studied including social technologies, audio/video conferences, e-learning, data bases, CRM systems, ERP systems, decisionmaking systems, expert systems, and data mining (Table 9). In all cases, large enterprises applied ICT tools more intensively. As a rule, small enterprises had the lowest intensity of ICT tools application. With some exceptions, the Tukey-Kramer test indicated that significant differences were observed between small and large enterprises. Significant differences were found for CRM systems and decision-making systems in the pair of small-medium enterprises as well as for social technologies, data bases, and data mining in the pair of medium-large enterprises.

Table 9. Intensity of ICT tools application in small, medium, and large enterprises

\begin{tabular}{|c|c|c|c|c|c|c|}
\hline & $\begin{array}{l}\text { Small } \\
\text { (S) }\end{array}$ & $\begin{array}{l}\text { Medium } \\
\text { (M) }\end{array}$ & $\begin{array}{l}\text { Large } \\
\text { (L) }\end{array}$ & $F$-value & $\begin{array}{l}p \text {-value } \\
\text { (significance) }\end{array}$ & $\begin{array}{l}\text { Significant } \\
\text { differences } \\
\text { between groups } \\
\text { by Tukey-Kramer } \\
\text { test }\end{array}$ \\
\hline $\begin{array}{l}\text { Social } \\
\text { technologies }\end{array}$ & 2.76 & 2.47 & 3.32 & 3.89 & 0.0242 & $M-L$ \\
\hline $\begin{array}{l}\text { Audio/video } \\
\text { conferences }\end{array}$ & 1.45 & 2.17 & 2.55 & 4.89 & 0.0096 & S-L \\
\hline E-learning & 1.38 & 2.23 & 2.42 & 4.84 & 0.0102 & S-L \\
\hline Data bases & 2.72 & 3.03 & 3.68 & 7.44 & 0.0010 & S-L, M-L \\
\hline CRM systems & 0.13 & 1.37 & 1.87 & 4.09 & 0.0199 & S-M, S-L \\
\hline ERP systems & 0.34 & 1.10 & 1.45 & 4.29 & 0.0167 & S-L \\
\hline $\begin{array}{l}\text { Decision- } \\
\text { making } \\
\text { systems }\end{array}$ & 0.27 & 0.96 & 1.42 & 4.77 & 0.0107 & S-M, S-L \\
\hline $\begin{array}{l}\text { Expert } \\
\text { systems }\end{array}$ & 0.31 & 1.00 & 1.38 & 3.83 & 0.0255 & S-L \\
\hline Data mining & 0.07 & 0.97 & 1.13 & 5.30 & 0.0067 & S-L, M-L \\
\hline
\end{tabular}

As compared to small enterprises, large enterprises used more intensively audio/video conferences, e-learning, data bases, CRM systems, ERP systems, decision-making systems, expert systems, and data mining. The differences between large and medium enterprises reached significant level for a few tools (social technologies, data bases, and data mining) only. 


\section{DISCUSSION}

The results concerning RQ 1-4 shed light on both similar and specific characteristics of KM initiatives in various categories of Ukrainian enterprises. The results on RQ 1-2 show that all enterprises, regardless of their size, demonstrate a rather high awareness of organizational knowledge and KM importance for their businesses. This finding is slightly different than expected. Although a high awareness is typical for managers of large enterprises, it is generally accepted that SME managers tend to underestimate the importance of knowledge and KM for their businesses (Wong \& Aspinwall, 2004; Gourova, 2010). It was found that enterprises of various sizes significantly differ with regard to the development of formal KM policies (procedures) and their implementation through systematic organizational measures.

Although small and medium enterprises are traditionally treated as a homogeneous group (e.g., McAdam \& Reid, 2001; Hutchinson \& Quintas, 2008; Durst \& Edvardsson, 2012; Cerchione \& Esposito, 2017), the results on KM policies (procedures) highlight their distinctions. Medium and especially large enterprises put more systematic efforts to work out specific organizational procedures in order to support KM initiatives, whereas small enterprises tend to manage their knowledge in a less formal way, as part of their day-to-day activities, without the use of KM terminology and KM concepts (Hutchinson \& Quintas, 2008). For example, they provide vocational training to their employees within the frame of informal programs and are unlikely to consider this activity as a KM activity.

Small, medium, and large enterprises demonstrate obvious distinctions in consistency between their awareness of KM importance and KM policies which they actually apply. In the case of large enterprises, high awareness of KM importance was highly consistent with the implementation of KM policies at the level of organizational procedures. On the contrary, small enterprises demonstrated obvious inconsistency between their declared attitude to KM and the actual implementation of KM policies at an organizational level.

The results concerning RQ3 indicate that all enterprises, regardless of their size, tend to rely on traditional KM tools. Widely used by all categories, core KM tools included such human-centered tools as staff meetings, collaborative problem-solving sessions, learning by doing, mentoring/ coaching, brainstorming, conferences/exhibitions, and such ICT tools as e-mail, data bases, social technologies, and file archives. These KM tools can be characterized as well-known to employees, universal, easy to access, nonexpensive and not exclusively constructed for KM purposes. Their scope of application exceeded $90 \%$ in all categories studied. 
On the contrary, more advanced KM tools, at least for the Ukrainian market, were less spread in all categories, although the scope of their application differed in various categories. Such human-centered tools as communities of practice, process maps, knowledge maps, and such ICT tools as DMS, decision-making systems, ERP systems, cloud computing, expert systems, data mining, and groupware tools were applied by less than $45 \%$ of large enterprises, and less than $40 \%$ of medium enterprises. In small enterprises, the scope of advanced $\mathrm{KM}$ tools application did not exceed $10 \%$. Cerchione and Esposito (2017) claimed that SMEs use traditional KM tools more intensively rather than new and more updated ones. Our study shows that this conclusion can be extended to the category of large enterprises (at least for those located in Ukraine).

The results also show that all enterprises, regardless of their size, are more selective in their adoption of advanced KM tools, which are rather expensive, sophisticated, and skill-demanding. Their implementation requires financial investment, staff training, and changing organizational procedures, staff habits, and models of behavior. From personal communications with managers, it occurs that, in the case of large enterprises, the implementation of more advanced ICT tool is often not a matter of cost but rather a matter of expediency of investing. Managers expect to achieve a higher efficiency of decision making, control, return on investment, and effectiveness. Large enterprises plan investments in advanced ICT tools if these tools meet their business requirements and have the potential to generate added value. Since small enterprises possess scarce human and financial resources (e.g., Desouza \& Awazu, 2006; Gourova, 2010; Edvardsson \& Durst, 2013), advanced ICT tools are impermissibly expensive for them. But, due to rather simple business processes and high socialization inherent to this category, the implementation of advanced ICT tools is not always of vital necessity for them.

With regard to RQ4, the significant distinctions among small, medium, and large enterprises were revealed on the intensity of KM tools application. For a number of human-centered tools (previous experience analysis, mentoring/coaching, working groups, job rotation, off-site vocational training, and knowledge maps) and ICT tools (audio/video conferences, e-learning, data bases, CRM systems, ERP systems, decision-making systems, expert systems, and data mining), large enterprises demonstrated a significantly higher intensity of their application while small enterprises had the lowest intensity of their application. There were only a few significant pairwise distinctions between medium and large enterprises. Again, this finding challenges commonly accepted view of SMEs as a homogeneous category.

The study provides some indication of distinctions in KM approaches used by various categories of enterprises. Zieba et al. (2016) and Alexandru et al. 
(2019) identified two types of these approaches as deliberate and emergent. Most of large enterprises applied a deliberate approach to KM and could be characterized as "Conscious adopters." Being highly aware of knowledge and KM importance, conscious adopters introduce formal KM policies and staff training programs, they perform activities explicitly defined as $\mathrm{KM}$ activities, they appoint people responsible for $\mathrm{KM}$, and they demonstrate the highest scope and intensity of both traditional and advanced KM tools application.

In contrast to large enterprises, small enterprises are more likely to apply emergent approach to KM and could be characterized as "Unconscious adopters." In spite of a rather high awareness of knowledge and KM importance, they put less deliberate efforts into creating a proper organizational context to manage knowledge. They use informal KM policies and staff training programs, they perform less activities explicitly defined as KM activities, they are less likely to appoint people responsible for KM, and they use mainly traditional KM tools. They lag far behind conscious adopters according to the scope and intensity of advanced KM tools application. Probably, small enterprises do not consider staff training and KM tools, which they actually use, as a part of KM.

To determine the predominant KM approach in the category of medium enterprises is somewhat more difficult, as according to some indicators (availability of a person(s) responsible for KM activities, the scope of advanced KM tools application, intensity of working groups, CRM systems, and decision-making systems application) they show more similarity with large enterprises, while according to other indicators (performing activities explicitly identified as KM activities, intensity of data bases and data mining application) they show more similarity with small ones. It seems that medium enterprises are rather a mixed category, which includes both conscious adopters and unconscious adopters.

In contrast to our study, Alexandru et al. (2019) did not reveal any clear relationship between an SME's size and their KM approach. This discrepancy is likely to be explained by such differences in samplings as business sector, geographical localization and number of size categories studied. Sensibly, knowledge-intensive small enterprises located in European countries might possess a higher consciousness in terms of $\mathrm{KM}$ than small enterprises from mostly traditional business sectors located in a country with a transitional economy. In addition, Alexandru et al. (2019) analyzed only two categories of enterprises (small and medium), whereas our study incorporated three categories.

From the KBV perspective, natural socialization and a network of close communications among employees are crucial for the creation of shared tacit knowledge (collective knowledge), which serves as a source of sustainable growth and competitiveness (Spender, 1996). It seems that 
small enterprises do not have a strong need to develop formal KM policies and apply sophisticated KM tools, even if they have the resources to invest in KM programs. Potentially, they can create collective knowledge with less management intervention than larger enterprises. On the contrary, large enterprises should put more effort into generating collective knowledge and satisfying their knowledge needs. These arguments seem to explain why small enterprises can afford to rely on an emergent approach to KM and remain unconscious adopters, whereas larger enterprises should apply a deliberate approach to KM and become conscious adopters.

The findings of the study challenge another commonly accepted view concerning the relation between enterprise category and Hansen's type of strategy (Hansen et al., 1999). Previously, it was shown that SMEs tend to rely on the personalization strategy (Becerra-Fernandez \& Sabherwall, 2008) and they are most likely to apply human-centered tools based on personal communication and cooperation (Desouza \& Awazu, 2006; Merono-Cerdan, Lopez-Nikolas, \& Sabater-Sanchez, 2007). On the contrary, large enterprises are more likely to adopt a codification strategy based on the intensive use of ICT tools (Maier, 2002; Sun \& Scott, 2005; Subashini et al., 2012; Merlo, 2016).

Our study revealed that, managing their knowledge, enterprises of various sizes did not give preference to either a personalization strategy (supported by human-centered tools) or a codification strategy (supported by ICT tools). Instead, elements of both strategies were used simultaneously and coherently, however, to varying extent. As Edwards (2009) stated, the elements of these strategies could complement each other giving a synergetic effect. Contrary to expectations, small enterprises did not follow a personalization strategy to a greater extent than other enterprises. In fact, many small enterprises applied human-centered tools less than medium and large enterprises. For all size categories, their KM policies, as well as the characteristics of human-centered tools and ICT tools applications, were interrelated with each other, demonstrating the balance between social and technical elements within an organizational context.

\section{CONCLUSION}

Although KM is an intensively studied domain, it remains, however, rather unclear in which KM aspects the small, medium, and large enterprises distinguish from each other. The comparative analysis of KM initiatives differentiating small, medium, and large organizations is hindered by the lack of empirical data and belongs to the underestimated area of KM. The purpose of this study was to conduct a comparative analysis of KM initiatives 
in small, medium, and large enterprises operating in Ukraine and highlight the specific characteristics of KM policies, as well as the scope and intensity of KM tools application in these categories.

The study allows us to answer RQ1: Do small, medium, and large Ukrainian enterprises differ in their awareness of knowledge/KM importance? All enterprises surveyed, regardless of their size, demonstrate rather high awareness of knowledge/KM importance for their businesses. The study allows us to answer RQ2: Do small, medium, and large Ukrainian enterprises apply distinctive KM policies? The enterprises of various sizes showed significant distinctions regarding availability of formal KM policies and staff training programs, performance of activities explicitly defined as KM activities, and availability of person(s) assigned to KM initiatives. In all cases, large enterprises demonstrated the highest scores according to these indicators, and small enterprises demonstrated the lowest scores. Obvious distinctions among small, medium, and large enterprises were found in the consistency between their attitudes to KM and KM policies which they actually apply. In the case of large enterprises, high awareness of KM importance was highly consistent with the implementation of KM policies at the level of organizational procedures. On the contrary, small enterprises demonstrated an obvious inconsistency between the declared attitude to KM and the actual implementation of KM policies at the organizational level. Medium enterprises according to this indicator were more similar to large enterprises than to small ones. The study provides the answer to RQ3: Do small, medium, and large Ukrainian enterprises differ in the scope of KM tools application? All enterprises, regardless of their size, tend to apply traditional and not exclusively constructed for KM purposes human-centered and ICT tools. Significant differences among small, medium, and large enterprises were observed in the scope of more advanced KM tools application. The scope of advanced KM tools application among small enterprises was substantially lower as compared to medium and especially large enterprises. The study provides the answer to RQ4: Do small, medium, and large Ukrainian enterprises differ in the intensity of KM tools application? The distinctions among various categories were found in terms of the intensity of KM tools application. According to many studied KM tools, both traditional and more advanced, small enterprises lag far behind large enterprises, although the distinctions between large and medium enterprises were less visible and, in most cases, insignificant.

To sum up, the findings of the paper outlined some substantial differences among small, medium, and large enterprises in terms of their KM policies, the intensity of KM tools application, and the scope of more sophisticated KM tools application. The most consistent KM policies and the highest scope and intensity of KM tools application were found in large 
enterprises, which presumably apply a deliberate KM approach and manage their knowledge consciously. Informal KM policies and the lowest scope and intensity of KM tools application were observed in small enterprises, which presumably rely on an emergent KM approach. It seems that medium enterprises rather belong to a mixed category, although the deliberate KM approach is somewhat predominant.

An important finding of this study is that, in contrast to the common view on SMEs as a homogeneous sector in terms of KM initiatives, obvious evidence of SMEs heterogeneity was obtained. According to a number of studied indicators, significant differences were observed between small and large enterprises, whereas the differences between medium and large enterprises were less obvious. Presumably, in terms of KM initiatives, medium enterprises are more similar to large enterprises than to small ones. In the scientific literature, it is generally accepted that SMEs manage their knowledge differently as compared to large enterprises. The results of the study allow us to specify this view, namely small, medium and large enterprises manage their knowledge in different ways. However, it is impossible to say that one category of enterprises is more successful in $\mathrm{KM}$ than another at this stage.

Regardless of their size, all enterprises operate in a highly competitive environment and understand the importance of knowledge and $\mathrm{KM}$ in achieving their strategic goals, organizational development, and business success. At the same time, they implement and use organizational measures (KM policies and tools) to varying degrees to meet their knowledge needs. And this is not so much due to the obvious differences in their financial resources and managerial skills, as to the different needs for knowledge and, at the same time, to the different approaches to meeting these needs. It seems that high socialization inherent in small enterprises is a natural facilitator for the formation and dissemination of collective knowledge, the most valuable resource of the organization, and requires special organizational measures to support themselves to a lesser extent than medium and large enterprises. Medium and especially large enterprises, due to departmental fragmentation and a complex network of communications, must make much more efforts to form and disseminate collective knowledge, deliberately implementing appropriate KM policies and tools. This point of view is supported by differences between the various categories of enterprises regarding the level of formalization of their KM policies, and the scale and intensity of the application of both human-centered and ICT tools.

The theoretical contribution of this study is that evidence has been provided for the heterogeneity of the SMEs sector by a number of KM characteristics, such as KM policies, and the scope and intensity of some human-centered and ICT tools application. Medium enterprises tend to apply 
KM approaches in a similar way to those applied by large enterprises. This finding allows us to deepen our knowledge of the conceptual differences in KM approaches applied by different enterprise categories.

On the basis of the study, some practical implications can be formulated. In order to foster collective knowledge creation and sharing, managers should promote internal communications, tacit knowledge sharing, and encourage employees to contribute to organizational knowledge creation. However, different KM approaches can be recommended for businesses of different sizes. Enterprise size should be taken into account when designing specific KM policies, programs, and tools to meet their needs to a greater extent. The larger the enterprise is, the more structured, deliberate, and conscious the KM approach that should be applied is.

Since our study was exploratory, it had some limitations stemming from the sampling methodology. Its clear limitation is the relatively small number of respondents. Further, the convenience sample was not fully representative regarding the structure of small, medium, and large enterprises in the country. The sampling was not random in terms of geographical location of the enterprises studied. In view of these limitations, the generalizability of the results is restricted and they should be considered as indicative.

The study allows us to identify the directions for further research on the KM topic studied. Shifting from the traditional comparison format in KM area of "SMEs versus large enterprises" to the format "small enterprises versus medium enterprises versus large enterprises" will allow for a better understanding of the features of KM policies, procedures, tools, and practices among organizations of various size. Potentially, the less structured, less consistent and less conscious KM approach demonstrated by small enterprises could satisfy their knowledge needs to the same extent as the structured, consistent and conscious KM approach could satisfy the knowledge needs of larger enterprises. Further research is needed to determine how the different KM approaches used by small, medium, and large enterprises affect the efficiency of decision-making processes, organizational productivity, and, ultimately, organizational competitiveness.

\section{References}

Alavi, M., \& Leidner, D.E. (2001). Review: knowledge management and knowledge management systems: Conceptual foundations and research issues. MIS Quarterly, 25(1), 107-136. http://doi.org/10.2307/3250961.

Alexandru V. A., Bolisani E., Andrei A. G., Cegarra-Navarro J. G., Martínez Martínez A., Paiola M., Scarso E., Vătămănescu E.-M., \& Zięba M. (2019). Knowledge management approaches of small and medium- 
sized firms: a cluster analysis. Kybernetes, 49(1), 73-87. https://doi. org/10.1108/k-03-2019-0211.

Anand, A., \& Walsh, I. (2016). Should knowledge be shared generously?

Tracing insights from past to present and describing a model. Journal of Knowledge Management, 20(4), 713-730. https://doi.org/10.1108/jkm10-2015-0401.

Bagozzi, R., Yi, Y., \& Phillips, L. W. (1991). Assessing construct validity in organization research. Administrative Science Quarterly, 36, 421-458. https://doi.org/10.2307/2393203.

Becerra-Fernandez, R., \& Sabherwal, I. (2010). Knowledge management: Systems and processes (1st ed.). Armonk: M.E. Sharpe.

Bergeron, B. (2003). Essentials of knowledge management (Essentials Series). New York: John Wiley \& Sons.

Bolisani, E., Zieba, M., Paiola M., \& Scarso E. (2017) Knowledge management strategies in KIBS companies: A preliminary analysis. In G. Spender, G. Schiuma, \& T. Gavrilova (Eds.), Proceedings of International Forum on Knowledge Assets Dynamics (pp. 1598-1611). St. Petersburg: St. Petersburg University.

Cantú, L. Z., Criado, J. R., \& Criado, A. R. (2009). Generation and transfer of knowledge in IT-related SMEs. Journal of Knowledge Management, 13(5), 243-256. https://doi.org/10.1108/ 13673270910988088.

Cardoni, A., Zanin, F., Corazza, G., \& Paradisi, A. (2020). Knowledge management and performance measurement systems for SMEs' economic sustainability. Sustainability, 12(7), 2594, https://doi. org/10.3390/su12072594.

Centobelli, P., Cerchione, R., \& Esposito, E. (2019). Efficiency and effectiveness of knowledge management systems in SMEs. Production Planning \& Control, 30(9), 779-791, https://doi.org/10.1080/09537287.2019.1582818.

Cerchione, R., \& Esposito, E. (2017). Using knowledge management systems: A taxonomy of SME strategies. International Journal of Information Management, 37(1), 1551-1562. https://doi.org/ 10.1016/j. ijinfomgt.2016.10.007.

Dalkir, K. (2017). Knowledge management in theory and practice (3rd ed.). Cambridge: MIT Press.

Davenport, M., \& Prusak, L. (1998). Working knowledge: How organizations manage what they know. Boston: Harvard Business School Press.

Desouza, K. C., \& Awazu, Y. (2006). Knowledge management at SMEs: Five peculiarities. Journal of Knowledge Management, 10(1), 32-43. https:// doi.org/10.1108/13673270610650085.

Du Plessis, M. (2005). Drivers of knowledge management in the corporate environment. International Journal of Information Management, 25(3), 193-202. https://doi.org/10.1016/ j.ijinfomgt.2004.12.001.

Durst, S. \& Bruns, G. (2018). Knowledge management in small and mediumsized enterprises. In J. Syed, P. Murray, D. Hislop, \& Y. Mouzughi (Eds.), 
The Palgrave Handbook of Knowledge Management (pp. 495-514). London: Palgrave Macmillan.

Durst, S., \& Edvardsson, I. R. (2012). Knowledge management in SMEs: A literature review. Journal of Knowledge Management, 16(6), 879-903. https://doi.org/10.1108/13673271211276173.

Edwards, J. S. (2009). Business processes and knowledge management. In M. Khosrow-Pour (Ed.), Encyclopedia of Information Science and Technology (I, pp. 471-476). Hershey: IGI Global. https://doi.org/10.4018/978-160566-026-4.ch078.

Edvardsson, I. R., \& Durst, S. (2013). The benefits of knowledge management in small and medium-sized enterprises. Procedia-Social and Behavioral Sciences, 81, 351-354. https://doi.org/ 10.1016/j.sbspro.2013.06.441ISI.

Evangelista, P., Esposito, E., Lauro, V., \& Raffa, M. (2010). The adoption of knowledge management systems in small firms. Electronic Journal of Knowledge Management, 8(1), 33-42. Retrieved from https:// www.researchgate.net/publication/228951380_The_Adoption_of_ Knowledge_Management_Systems_in_Small_Firms.

European Commission. (2016). Current SMEs definition. Retrieved from https://ec.europa.eu/ growth/smes/business-friendly-environment/ sme-definition.

Fong, P.S.W., \& Lee, H. F. (2009). Acquisition, reuse and sharing of knowledge in property management firms. Facilities, 27(7-8), 291-314. https://doi. org/10.1108/02632770910956148.

García-Alvarez, M. T. (2015). Analysis of the effects of ICTs in knowledge management and innovation: The case of Zara Group. Computers in Human Behavior, 51, 994-1002. https://doi.org/10.1016/j. chb.2014.10.007.

Gourova, E. (2010). Knowledge management strategy for small and medium enterprises. In H. Fujita \& J. Sasaki (Eds.), Proceedings of the International Conference on Applied Computer Science (pp. 639-648). Stevens Point: World Scientific and Engineering Academy and Society (WSEAS). Retrieved from http://www.wseas.us/e-library/conferences/2010/ Malta/ACS/ACS-105.pdf.

Grant, R. M. (1996). Toward a knowledge-based theory of the firm. Strategic Management Journal, 17, 109-122. https://doi.org/10.1002/ smj.4250171110.

Greiner, M. E., Bohmann, T., \& Krcmar, H. (2007). A strategy for knowledge management. Journal of Knowledge Management, 11(6), 3-15. http:// doi.org/10.1108/13673270710832127.

Gupta, B., Iyer, L. S., \& Aronson, J. E. (2000). Knowledge management: Practices and challenges. Industrial Management \& Data Systems, 100(1), 17-21. https://doi.org/10.1108/02635570010273018.

Hansen, M. T., Nohria, N., \& Tierney, T. (1999). What's your strategy for managing knowledge? Harvard Business Review, March-April, 1-11. 
Retrieved from https://hbr.org/1999/03/whats-your-strategy-formanaging-knowledge.

Hutchinson, V., \& Quintas, P. (2008). Do SMEs do knowledge management? Or simply manage what they know? International Small Business Journal, 26(2), 131-134. https://doi.org/10.1177/0266242607086571.

Ibrahim, F., Reid, V., \& Edgar, D. (2009). Assessing the role of knowledge management in adding value: Moving towards a comprehensive framework. Journal of Information and Knowledge Management, 8(4), 275-286. https://doi.org/10.1142/S0219649209002397.

Ілляшенко, С.М., Шипуліна, Ю.С., \& Ілляшенко Н.С. (2019). Управління знаннями при формуванні стратегії випереджаючого інноваційного розвитку підприємства [Knowledge management in forming a strategy of inovative development of the enterprise]. Проблеми системного підходу в економіuі / Problems of Systemic Approach in the Economy, 3(71), 215-223. Retrieved from http://essuir.sumdu.edu.ua/ handle/123456789/7396.

Inkinen, H., Kianto, A., \& Vanhala, M. (2015). Knowledge management practices and innovation performance in Finland. Baltic Journal of Management, 10(4), 432-455. https://doi.org/ 10.1108/bjm-10-2014-0178.

Jelavic, M. (2011). Socio-technical knowledge management and epistemological paradigms: Theoretical connections at the individual and organisational level. Interdisciplinary Journal of Information, Knowledge, and Management, 6(1), 1-16. https://doi.org/10.28945/1337.

King, W. R. (2009). Knowledge management and organizational learning. Annals of Information Systems, 4, 3-13. https://doi.org/10.1007/978-14419-0011-1_1.

KPMG Consulting. (2000). Knowledge management research report. London: KPMG Consulting. Retrieved from http://www.providersedge.com/docs/ km_articles/KPMG_KM_Research_Report_2000.pdf.

Leiner, D. J. (2017). Our research's breadth lives on convenience samples. A case study of the online respondent pool SoSci Panel. Studies in Communication and Media (SCM), 5(4), 367-396. https://doi. org/10.5771/2192-4007-2016-4-36769-134.

Levine, D. M., Stephan, D. F., Krehbiel, T. C., \& Berenson, M. L. (2008). Statistics for managers: Using Microsoft Excel (5th ed.). Boston: Pearson Custom Publishing.

Maier, R. (2002). Knowledge Management Systems: Information and Communication Technologies for Knowledge Management. Berlin: Springer-Verlag.

Marr, B., Gupta, O., Pike, S., \& Roos, G. (2003). Intellectual capital and knowledge management effectiveness. Management Decision, 41(8), 771-781. https://doi.org/10.1108/00251740310496288.

Martelo-Landroguez, S., \& Cegarra-Navarro, J. G. (2014). Linking knowledge corridors to customer value through knowledge processes. Journal of 
Knowledge Management, 18(2), 342-365. https://doi.org/10.1108/jkm07-2013-0284.

Massaro, M., Handley, K., Bagnoli, C., \& Dumay, J. (2016). Knowledge management in small and medium enterprises: A structured literature review. Journal of Knowledge Management, 20(2), 258-291. https://doi. org/10.1108/jkm-08-2015-0320

McAdam, R., \& Reid, R. (2001). SME and large organization perceptions of knowledge management: Comparisons and contrasts. Journal of Knowledge Management, 5(3), 231-241. https://doi. org/10.1108/13673270110400870.

Merlo, T. R. (2016). Factors influencing knowledge management use in technology enterprises in the Southern United States. Procedia Computer Science, 99, 15-35. https://doi.org/10.1016/ j.procs.2016.09.098.

Merono-Cerdan, A. L., Lopez-Nicolas, C., \& Sabater-Sanchez, R. (2007). Knowledge management strategy diagnosis from $\mathrm{KM}$ instruments use. Journal of Knowledge Management, 11(2), 60-72. https://doi. org/10.1108/13673270710738915.

Nonaka, I. (1994). A dynamic theory of organizational knowledge creation. Organization Science, 5(1), 14-37. https://doi.org/10.1287/orsc.5.1.14.

Pan, S. L., \& Scarbrough, H. (1999). Knowledge management in practice: An exploratory case study. Technology Analysis and Strategic Management, 11(3), 359-374. https://doi.org/ 10.1080/095373299107401.

Paolini, M., Coluccia, D., Fontana, S., \& Solimene, S. (2020). Knowledge management, intellectual capital and entrepreneurship: A structured literature review. Journal of Knowledge Management, 24 (8), 17971818. https://doi.org/10.1108/JKM-01-2020-0052

Pinget, A., Bocquet, R. \& Mothe, C. (2015). Barriers to environmental innovation in SMEs: empirical evidence from French firms. M@n@ gement, 18(2), 132-155. https://doi.org/10.3917/ mana.182.0132.

Podsakoff, P. M. \& Organ, D. (1986). Self-report in organizational research. Journal of Management, 12(4), 531-544. https://doi. org/10.1177/014920638601200408.

Podsakoff, P. M., MacKenzie, S. B., Lee, J.-Y., \& Podsakoff, N. P. (2003). Common method biases in behavioral research: A critical review of the literature and recommended remedies. Journal of Applied Psychology, 88(5), 879903. https://doi.org/10.1037/0021-9010.88.5.879.

Polyakov, M. V. (2017). Positive impact of international companies on development of knowledge economy. Problems and Perspectives in Management, 15(2), 81-89. http://doi.org/10.21511/ ppm.15(2).2017.08.

Поляков, М. В. (2017). Особливості розвитку міжнародного бізнесу в умовах становлення глобальної економіки знань [Features of international business development in the conditions of global knowledge economy]. Економічний простір / Economic Environment, 121, 47-57. Retrieved from http://nbuv.gov.ua/ujrn/ecpros_2017_121_6. 
Prystupa-Rządca, K. (2014). Zarządzanie wiedzą w organizacjach born global. Warsaw: Sedno.

Serenko, A. (2013). Meta-analysis of scientometric research of knowledge management: Discovering the identity of the discipline. Journal of Knowledge Management, 17(5), 773-812. https:://doi.org/10.1108/ jkm-05-2013-0166.

Singh, R. K., Garg, S. K. \& Deshmukh, S. G. (2008). Strategy development by SMEs for competitiveness: A review. Benchmarking: An International Journal, 15(5), 525-547. https:://doi.org/10.1108/14635770810903132.

Ситник Н. І. (2017). Організаційне навчання як складова менеджменту знань [Orgaizational knowledge and knowledge management]. Менеджмент і маркетинг інновацій / Management and Marketing of Innovations, 3, 346-354. http://doi.org/10.21272/mmi.2017.3-32.

Soon, T. T., \& Zainol, F. A. (2011). Knowledge management enablers, process and organizational performance: Evidence from Malaysian enterprises. Asian Social Science, 7(8), 186-192. https://doi.org/10.5539/ass. v7n8p186.

Spender, J.-C. (1996). Making knowledge the basis of a dynamic theory of the firm. Strategic Management Journal, 17, 45-62. https://doi. org/10.1002/smj.4250171106.

Subashini, R., Rita, S., \& Vivek, M. (2012). The role of ICTs in knowledge management (KM) for organizational effectiveness. In P. V. Krishna, M. R. Babu, \& E. Ariwa (Eds.), Global Trends in Information Systems and Software Applications. ObCom 2011. Communications in Computer and Information Science (pp. 542-549). Berlin, Heidelberg: Springer. https:// doi.org/10.1007/978-3-642-29216-3_59.

Sun, P. Y.-T, \& Scott, J. L. (2005). An investigation of barriers to knowledge transfer. Journal of Knowledge Management, 9(2), 75-90. https://doi. org/10.1108/13673270510590236.

Susanty, A., Yuningsih, Y., \& Anggadwita, G., (2019). Knowledge management practices and innovation performance: A study at Indonesian Government apparatus research and training center. Journal of Science and Technology Policy Management. 10(2). 301-318. https://doi.org/ 10.1108/jstpm-03-2018-0030.

Uriarte, F. (2008). Introduction to knowledge management. Jakarta: ASEAN Foundation. https://doi.org/10.4236/jsea.2012.51006 5,032.

Von Krogh, G., Ichijo, K., \& Nonaka, I. O. (2000). Enabling Knowledge Creation: How to Unlock the Mystery of Tacit Knowledge and Release the Power of Innovation. Oxford: Oxford University Press.

Wong, K. Y., \& Aspinwall, E. (2004). Characterizing knowledge management in the small business environment. Journal of Knowledge Management, 8(3), 44-61. https://doi.org/10.1108/ 13673270410541033.

Xue, C. T. S. (2017). A literature review on knowledge management in organizations. Research in Business and Management, 4(1), 30-41. https://doi.org/10.5296/rbm.v4i1.10786. 
Zheng, T. (2017). A literature review on knowledge sharing. Open Journal of Social Sciences, 5(3), 51-58. https://doi.org/10.4236/jss.2017.53006.

Zieba, M., Bolisani, E., \& Scarso, E. (2016). Emergent approach to knowledge management by small companies: Multiple case-study research. Journal of Knowledge Management, 20(2), 292-307. https://doi.org/10.1108/ jkm-07-2015-0271.

\begin{abstract}
Abstrakt
CEL: Celem niniejszego opracowania było przeprowadzenie analizy porównawczej inicjatyw zarzq̨dzania wiedzq (KM) w małych, średnich i dużych przedsiębiorstwach działajqcych na Ukrainie oraz podkreślenie specyfiki polityk KM, a także zakresu i intensywności aplikacyjnych narzędzi KM w tych kategoriach. W szczególności badanie koncentrowało się na spójności między świadomościq znaczenia wiedzy/KM i polityk $K M$, a zakresem i intensywnościq stosowania zarówno narzędzi skoncentrowanych na człowieku, jak i narzędzi technologii komunikacji informacyjnej (ICT). METODYKA: Koncepcja badania została opracowana w oparciu o integracyjnq perspektywę społeczno-technicznq. Dane empiryczne uzyskano poprzez badanie ankietowe wśród 90 menedżerów małych, średnich i dużych przedsiębiorstw ukraińskich, których wyniki poddano analizie statystycznej. WYNIKI: Podkreślono zarówno wspólne, jak i wyróżniajqce cechy tych kategorii pod względem KM. Chociaż wszystkie przedsiębiorstwa, niezależnie od wielkości, wykazywały wysokq świadomość znaczenia wiedzy/KM dla prowadzonej przez nich działalności, to jednak stwierdzono istotne różnice pomiędzy małymi i dużymi przedsiębiorstwami w odniesieniu do ich polityki $K M$, zakresu stosowania zaawansowanych narzędzi KM oraz intensywności niektórych z nich, tradycyjne i zaawansowane aplikacje narzędzi KM. We wszystkich przypadkach przedsiębiorstwa duże wykazywały wyższy poziom tych cech w porównaniu z przedsiębiorstwami małymi, natomiast przedsiębiorstwa średnie były bardziej zbliżone do przedsiębiorstw dużych. W przeciwieństwie do powszechnego pogladu na MŚP jako sektor jednorodny pod względem KM, badanie pokazuje jego niejednorodność pod względem inicjatyw KM. Według szeregu badanych wskaźników zaobserwowano istotne różnice między małymi i dużymi przedsiębiorstwami, natomiast różnice między średnimi i dużymi przedsiębiorstwami były znacznie mniej oczywiste. IMPLIKACJE DLA TEORII I PRAKTYKI: Teoretycznym wkładem tego badania było dostarczenie dowodów na heterogeniczność sektora MŚP w oparciu o szereg cech KM. To odkrycie pozwala nam pogłębić naszq wiedzę na temat różnic pojęciowych w podejściach KM, stosowanych przez różne kategorie przedsiębiorstw. Z praktycznego punktu widzenia, przy projektowaniu konkretnych polityk, programów i narzędzi $K M$, które w większym stopniu zaspokajajq potrzeby przedsiębiorstw, należy wziq̨ć pod uwagę wielkość przedsiębiorstwa. Im większe przedsiębiorstwo, tym bardziej ustrukturyzowane, celowe i świadome podejście do KM, które należy zastosować. ORYGINALNOŚĆ I WARTOŚĆ: Nie przeprowadzono wcześniej żadnych badań empirycznych, które dotyczyłyby analizy porównawczej inicjatyw KM w małych, średnich i dużych przedsiębiorstwach działajqcych na Ukrainie, a także w innych transformujqcych się gospodarkach państw postsowieckich.
\end{abstract}


Słowa kluczowe: zarzqdzanie wiedzq, świadomość zarzqdzania wiedzq, polityka zarządzania wiedzq, narzędzia zorientowane na człowieka, narzędzia ICT, małe, średnie i duże przedsiębiorstwa

\section{Biographical notes}

Natalia Sytnik is an associate professor at the Management Department of the National Technical University of Ukraine "Igor Sikorsky Kyiv Polytechnic Institute", Ukraine. Her research interests are related to the "human" side of knowledge management and organizational creativity. She is the author of numerous publications on knowledge management, organizational learning, human resources and startup management.

Maryna Kravchenko is a Doctor of Science in economics, specializing in management sciences. She is a Professor at the Management Department of the National Technical University of Ukraine "Igor Sikorsky Kyiv Polytechnic Institute," Ukraine. She is the Head of the Bachelor's and Master's Programs "Management of Investment and Innovation." Her research areas include innovation management, startup management, and enterprise sustainable development management. She is the editor-in-chief of the academic journal "Economic Bulletin of the National Technical University of Ukraine "Kyiv Polytechnic Institute" and a member of the editorial board of the economic scientific journal "Entrepreneurship and Innovation." Since 2015, she has been a member of a working group of World Data Center for Geoinformatics and Sustainable Development to develop a Foresight of the Ukrainian Economy for mid-term and long-term time horizons. She is the author or co-author of more than 200 publications, including three monographs and four textbooks for university students.

\section{Conflicts of interest}

The authors declare no conflict of interest.

\section{Citation (APA Style)}

Sytnik, N., Kravchenko, M. (2021). Application of knowledge management tools: Comparative analysis of small, medium, and large enterprises. Journal of Entrepreneurship, Management, and Innovation, 17(4), 121-156. https:// doi.org/10.7341/20211745 